\title{
NANNOGERMALUS MARMORATUS: A NEW ENDEMIC BIG-EYED BUG FROM NEW CALEDONIA (HETEROPTERA: LYGAEOIDEA: GEOCORIDAE)
}

\author{
PÉTER KóBor ${ }^{1}$ and Elố Kondorosy ${ }^{2}$ \\ ${ }^{1}$ Department of Nature Conservation and Ecology, Herman Ottó Institute Non-profit Ltd. \\ H-1223 Budapest, Park u.2, Hungary; E-mail: kobor.peter@hoi.hu, p.kobor@gmail.com \\ https://orcid.org/0000-0003-0266-7303 \\ ${ }^{2}$ Department of Animal Science, Szent István University, Georgikon Faculty \\ H-8360 Keszthely, Deák street 16, Hungary \\ E-mail: kondorosy.ee@gmail.com, https://orcid.org/0000-0001-7162-0862
}

Nannogermalus gen. nov. and its type-species Nannogermalus marmoratus sp. nov. (Hemiptera: Heteroptera: Lygaeoidea: Geocoridae: Geocorinae) is described from New Caledonia. The placement of the genus within the subfamily Geocorinae is discussed.

Key words: Heteroptera, Geocoridae, Lygaeoidea, New Caledonia, new genus, new species.

\section{INTRODUCTION}

The archipelago of New Caledonia is considered one of the world's biodiversity hotspots (Mittermeier et al. 1998, Myers et al. 2000) where endemic terrestrial biota is actually threatened by ongoing habitat loss (BRADFORD \& JAFFrÉ 2004) caused by deforestation, opencast mining of rare metal ores (PASCAL et al. 2008) and introduction of exotic species (GARGOMiny et al. 1996).

The foundations of the research of Hemiptera fauna of the archipelago was published by the French missionary, Jean Xavier Hyacinthe Montrouzier (Montrouzier 1858, 1861, 1865), the French entomologist Arnold Lucien Montandon (Montandon 1907, 1913) and his British coeval, William Lucas Distant (Distant 1914, 1920). In recent years the Schizopteridae (e.g. Hill 2013, 2014) and Tingidae (e.g. Guilbert 2004, Murienne et al. 2009, Guilbert 2012) are the most studied heteropteran families of the region.

According to recent knowledge (Dellapé \& Henry 2020), the geocorine fauna of New Caledonia consists of two species considered to belong to genus Geocoris Fallén, 1814, two species of genus Germalus Stål, 1862 and two monotypic genera, Apennocoris Montandon, 1907 and Nesogermalus Bergroth, 1916. However, the taxonomic position of New Caledonian big-eyed bugs is doubtful (e.g. Montandon 1913, Bergroth 1916) due to the lost types of Montrouzier (SCHOUteden 1933) and remained virtually unstudied in the past decades. In the course of the study of heteropteran collections of multiple European natural history museums, a new, minute sized representative of subfamily 
Geocorinae was discovered. Hereby, authors present the description of this new taxon and, based on the pieces of evidence acquired by the study of exoskeletal and genital characters, formulate hypotheses regarding its placement within the subfamily.

\section{MATERIAL AND METHODS}

Abbreviation of depositories: BMNH - Natural History Museum, London, United Kingdom; MNHN - Museum National d'Historie Naturelle, Paris, France; NHMW Naturhistorisches Museum, Vienna, Austria.

Label data cited verbatim. Lines on labels are separated by "/", different labels are separated by "//".

Examination of exoskeletal and genital structures was performed with Leica Mz 95 stereoscopic and Keyence VHX 5000 digital microscopes. Photo documentation was done with Keyence VHX 5000 digital microscope. Genitalia were examined by removal of the whole abdomen and soaking it overnight in $10 \%$ lactic acid solution at room temperature. When soaking in lactic acid, structures remain more flexible than by $\mathrm{KOH}$ maceration according to author's experiences. This method also prevents from "over-clearing" of structures (BLAHNIK et al. 2007), thus additional dye staining is not necessary before further dissection, observation or photographic documentation.

Measurements were made using an ocular micrometre and were performed on scaled photos. Values are given in millimetres. Values for holotype indicated by bold letters. Range of paratypes given in parenthesis.

General morphological terminology used in this article was adapted from Tsai et al. (2011) and Malipatil \& Blackett (2013). Terminology for external structures of metathoracic scent efferent apparatus (MTSEA) was adapted from KMENT \& Vilimová (2010).

\section{RESULTS}

\section{Nannogermalus gen. $n$.}

(Figs 1-2)

Type species: Nannogermalus marmoratus sp. n.

Description. Head concave pentagonal in dorsal view. Eyes slightly stylate with ocular sulcus complete, well-defined. Vertex conspicuously slanted anteriad in lateral view. Vertex with three longitudinal furrows (most conspicuous in frontal view): two arched furrows situated medially to ocelli and a minute longitudinal furrow in the middle of vertex, extending to base of clypeus (Fig. 2A). Curved transversal furrows extending between subbasal part of clypeus and ocular sulcus. Clypeus with basal sutures distinct; divided in 1:2 ratio with transversal suture subapically (Fig. 2A). Antennomere I shortest, antennomeres II-III subequal, antennomere IV somewhat shorter than II-III. First three antennomeres cylindrical, segment IV conspicuously spindle formed. Venter of head deeply punctate. Labial trough open, V-shaped. Labiomere I not reaching base of head; labiomeres II-III subequal; labiomere IV shortest, reaching line of metacoxae. Thorax: Pronotum campanulate in dorsal view with slightly concave lateral margins, profile conspicuously gibbous. Surface with 
dense, deep irregular punctation. Pronotal callosities reduced to narrow, impunctate furrows, separated by a narrow longitudinal ridge. Humeral angles impunctate. Posterior margin with slight impressions near basal angles of scutellum. Scutellum sub-equilateral with margins slightly curved, apex sharply pointed; surface with dense punctation, similarly to pronotum; trifurcate carina T-shaped, somewhat widened in basal and apical angles, interrupted by few punctures medially. Hemelytron macropterous; membrane well developed, margin surpassing apex of abdomen. Clavus of hemelytron narrow, parallel sided; length of claval commissure less than half of median length of scutellum; scutellar margin with 4 punctures apically, corial margin completely punctate (Fig. 2C). Corium with a line of punctures along $\mathrm{Cu}$ and an arched line along $\mathrm{M}+\mathrm{R}$, continuing on apical corial margin laterad but not reaching apex; surface of intervannal areas rugose; apical margin of corium with slight impression by M; costal margin narrow. Prosternal margin collar-like, bulging with a line of punctures. Thoracic pleurites and sternites mostly with dense punctation, similar to pronotum except metapleurites above the MTSEA. Peritreme of MTSEA situated ventrolaterally, dorsal margin hardly exceeding line of supracoxal lobes; ostiole oblong, irregular; vestibular scar absent; evaporative area reduced to the surroundings of peritreme. Femora unarmed, length of tarsomere I subequal to sum of length of tarsomere II and III. Position of abdominal spiracles II-IV dorsal, V-VII ventral. Abdominal segments I-III inseparable; sutures of abdominal tergites IV/V and V/VI medially curved posteriad (Figs 1A, 2C). Apex of connexiva of segment VII protrusive (Fig. 2D). Genitalia: Male pygophore with dorsal opening rounded, lateral processes sharply pointed, apex of lateral process hooked. Parameres with blade long and slender, conspicuously curved; crossing each other in X-form in situ. Female ovipositor short, not exceeding genital capsule.

Diagnosis. Pentagonal head with moderately stylate, kidney-shaped eyes and the medially curved sutures of abdominal tergites IV/V and V/VI clearly demonstrate that the genus is a representative of the family Geocoridae. The position of abdominal spiracles confirms that the genus belongs to subfamily Geocorinae. The proportions of scutellum, the parallel margins of clavus, the punctation of corium and structures of male genitalia suggest a close relationship to New Caledonian Germalus species. The structure of MTSEA resembles more to representatives of Geocoris, e.g. the Australian Geocoris lubrus Kirkaldy, 1908 (specimens examined by the senior author). Based on the available data the taxon is considered to be closely related to Germalus and allied taxa. Nevertheless, the exact placement of this genus within Geocorinae should be subject of a phylogenetic analysis (in progress).

Besides the minute size compared to other geocorine bugs of the archipelago, Nannogermalus can be delimited by the conspicuously slanted vertex; punctate venter of head; campanulate pronotum with furrow-like callosities and T-shaped carina of scutellum.

Etymology. Masculine generic name. The naming of the genus indicates its close relationship with the geocorine genus Germalus Stål, 1862. Prefix "nanno-" comes from the Greek word "nannos" (small, minute) referring to the size of these insects: these insects are the smallest known representatives of big-eyed bugs. 


\section{Nannogermalus marmoratus sp. n.}

(Figs 1-2)

Holotype: đo (BMNH): Rhoo, / Houadou R., / New Caledonia. / 7. XI. 1914. / P. D. Montague. / 1918-87.

Paratypes: 1 q (BMNH): Up. Houailou R., / New Caledonia. / 4. VIII. 1914 / P. D. Montague. / 1918-87; 1 §ิ (BMNH): Rhoo, / Houdou R. / New Caledonia / 7. IX. 1914. P. D. Montague, / 1918-87; 1 § (NHMW): NEW CALED.: South Prov. / Mt. Mou / 400 m, 23. 11. 2001 / leg. Balke \& Wevalka (NC 52); 1 ô (MNHN): PR16NC07307 // NC - TR3508// NOUVELLECALEDONIE. Yaté. Ouinné/ OUI-MAL-2A: S 21.99906; E 166.62523; 190m/ 15-IX au 02-XII2016, E. Poirier leg. / AP A-NCPS-2016-025/ Expédition La Planéte Revisitée MNHN-PNI.
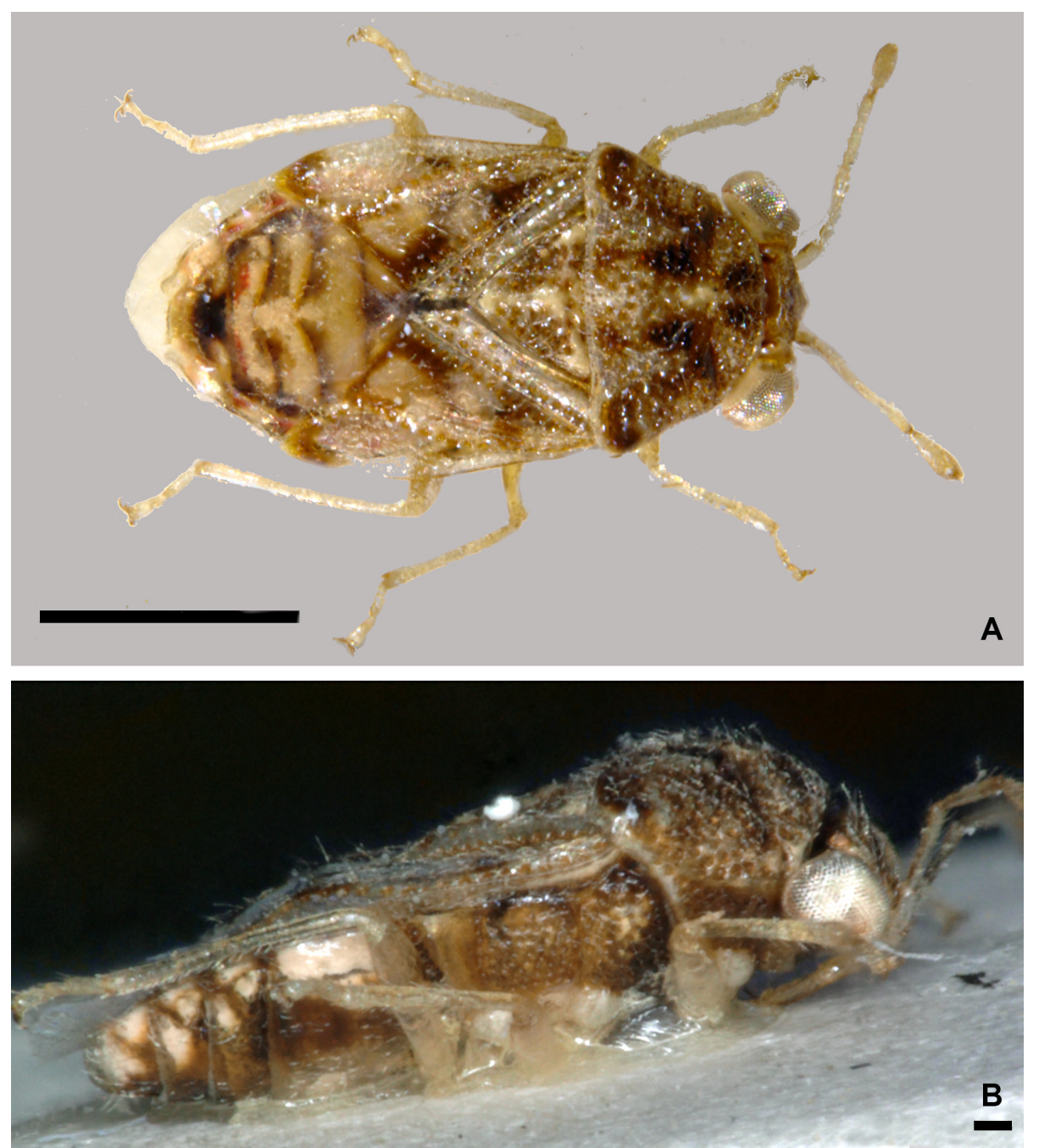

Fig. 1. Nannogermalus marmoratus (paratype male, NHMW): $\mathrm{A}=$ dorsal habitus, $\mathrm{B}=$ lateral view Scales: $A=1 \mathrm{~mm}, \mathrm{~B}=100 \mu \mathrm{m}$ 
Colouration. Ground colour ochraceous. Head: base of vertex and surroundings of sutures fuscous as in Figures 2A, C. Eyes and ocelli translucent; back of eyestalks pale ochraceous. Antenniferous tubercles brownish. Antennomeres and labiomeres without markings. Thorax: Thoracic punctation pale fuscous. Pronotum with extended, irregular fuscous spots. Dark brownish spot near midline of pronotum, at middle of callosities and humeral angles as in Figure 2B. Scutellar callosity somewhat paler than ground colour. Clavus and corium semi-translucent, ochraceous with pale fuscous punctation. Corium with irregular fuscous spots at claval and apical margin. Thoracic pleura with extended pale brownish regions as in figure 1B. Anterior margin of mesothorax with irregular, dark brownish band. Peritreme of MTSEA pale ochraceous. Legs semi-translucent, ochraceous, indecorate. Abdomen: Abdominal tergites IV-VI with irregular, anteriorly fading brownish spots near median curvature; spots of tergite VI infused with red; base of tergite VII with an extent blackish spot medially (fig. 1D). Abdominal connexiva with extended, irregular pale brownish regions.

Structure (characters not mentioned here are consonant with generic description). Body oval, covered with dense, short pubescence. Head: Ocellar distance to eye-ocellus distance: 1: 1. Ratio of antennomeres: 1: 2.3: 3.1: 3.6. Ratio of labiomeres: 1: 0.92: 0.83: 0.83. Thorax: Pronotum slightly keeled medially (fig. 2A). Pronotum ratio (basal width to median length): 1: 0.6. Trifurcate carina of scutellum T-shaped, thin, widened at basal and apical edges. Scutellum ratio (basal width to median): 1: 0.7. Length of claval commissure to median length of scutellum: 1: 2.5. Abdominal connexiva with sparse semi-erect pubescence.
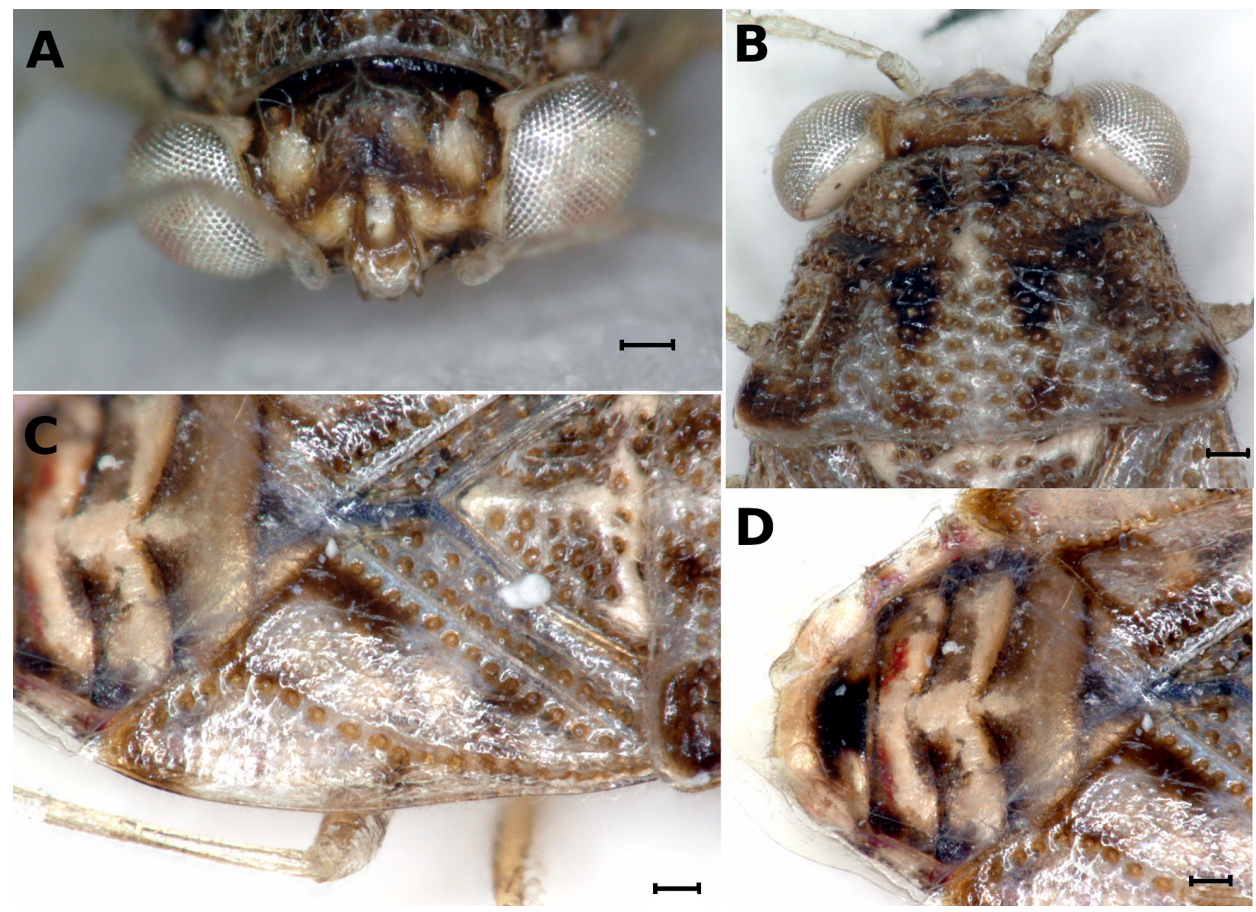

Fig. 2. Details of Nannogermalus marmoratus (paratype male, NHMW): $A=$ head in frontal view, $\mathrm{B}=$ head and pronotum, $\mathrm{C}=$ scutellum and hemelytron, $\mathrm{D}=$ abdomen. Scale: $100 \mu \mathrm{m}$ 
Measurements. total body length: 2.42 (2.36-2.40); head length: 0.15 (0.14-0.15); head width: 0.90 (0.88-0.90); ocellar distance: 0.34 (0.31-0.33); antennal segments (I-IV): 0.07-0.160.22-0.25 (0.05-0.07 - 0.13-0.15 - 0.20-0.21 - 0.23); labial segments (I-IV): 0.30-0.27-0.25.0.25 (0.28-0.30 - 0.25-0.26 - 0.23-0.23 - 0.22-0.23); pronotum length: $0.65(0.64-0.66)$; pronotum width: 1.09 (1.07-1.10); scutellum length: 0.37 (0.35-0.37); scutellum width: 0.55 (0.54-0.55); length of claval commissure: $0.15(0.13-15)$.

Diagnosis. Besides the structural characters listed in generic diagnosis, the species is to be recognised by its marmorated pattern (Fig. 2A). Colouration may vary within an extent, but general patterns were recognizable on all studied specimens.

Distribution. The specimens known to the authors were collected in along the Houadou River and Mont Mou Botanic Reserve.

Etymology. The name of species refers to its colouration and pattern: marmoratus $($ Latin $)=$ marbled .

\section{DISCUSSION}

New Caledonia is considered one of the unique regions of the world in terms of terrestrial and aquatic biota, with many yet undiscovered taxa. This monotypic genus can be considered as an example of this uniqueness.

The shape of the head and the curved sutures of abdominal tergites IV/V and V/VI allocate this new monotypic genus in the Geocorinae, but its relationships with other representatives of the subfamily is more complicated. The subequilateral scutellum, the parallel margins of the clavus and the punctation on corium suggest that $N$. marmoratus is closely related to other geocorine bugs of the archipelago currently classified in the genera Germalus and Nesogermalus. However, arrangement of MTSEA, e.g. the oval, ear-shaped ostiole and the reduced evaporatorium is similar to Geocoris species distributed in the Indomalayan or Australasian region. This controversy suggests that the placement of $N$. marmoratus should be subject of thorough phylogenetic analysis. Nevertheless, until the availability of further evidences, Nannogermalus is considered allied to genus Germalus.

\section{REFERENCES}

Bergroth, E. (1916): Heteropterous Hemiptera collected by Professor W. Baldwin Spenser during the Horn Expedition into Central Australia. - Proceedings of the Royal Society of Victoria 29: 19-39.

Blahnik, R. J., Holzenthal, R. W. \& Prather, A. L. (2007): The lactic acid method for clearing Trichoptera genitalia. - In: Proceedings of the 12th International Symposium on Trichoptera. The Caddis Press, Columbus, Ohio pp. 9-14. 
Bradford, J., \& JAFFré, T. (2004): Plant species microendemism and conservation of montane maquis in New Caledonia: two new species of Pancheria (Cunoniaceae) from the Roche Ouaième. -Biodiversity \& Conservation 13(12): 225-2274. https://doi. org/10.1023/B:BIOC.0000047901.33761.3c

Dellapé, P. M. \& T. J. Henry (2020): Lygaeoidea Species File. Version 5.0/5.0. http://Lygaeoidea.SpeciesFile.org [accessed on January 25, 2020]

Distant, W. L. (1914): Rhynchota from New Caledonia and the surrounding islands. - In: Sarasin, F. \& Roux, J. (eds): Nova Caledonia. Forschungen in Neu-Caledonien und auf den Loyalty-Inslen. Recherches scientifiques et Nouvelle-Calédonie et aux iles Loyalty. - Nova Caledonia Zool. 1 4(10): 369-390.

Distant, W. L. (1920): XIX. - Rhynchota from New Caledonia - Journal of Natural History, 6(31): 143-164. https://doi.org/10.1080/00222932008632426

Gargominy, O., Bouchet, P., Pascal, M., Jaffré, T. \& Tourneur, J. C. (1996): Conséquences des introductions d'espèces animales et végétales sur la biodiversité en NouvelleCalédonie. - Revue d'Ecologie Appliquée (La Terre et la Vie) 51: 375-402.

Guilbert, E. (2004): Immature stages of New Caledonian Tingidae (Heteroptera): description and development. - European Journal of Entomology 101: 261-272. https://doi. org/10.14411/eje.2004.036

Guilbert, E. (2012): Phylogeny of Cantacaderinae (Heteroptera: Tingidae) revisited after the description of a new genus and new species from New Caledonia. - European Journal of Entomology 109: 111-116. https://doi.org/10.14411/eje.2012.014

Hill, L. (2013): A revision of Hypselosoma Reuter (Insecta: Heteroptera: Schizopteridae) from New Caledonia. - Memoirs of the Queensland Museum 56(2): 407-455.

Hill, L. (2014): Revision of Silhouettanus with description of nine new species (Hemiptera: Heteroptera: Schizopteridae). - Zootaxa 3815(3): 353-385. https://doi.org/10.11646/ zootaxa.3815.3.3

Kment, P. \& Vilimova, J. (2010): Thoracic scent efferent system of Pentatomoidea. - Zootaxa 2706: $1-77$.

Malipatil, M. B. \& Blackett, M. J. (2013): Review and revision of Australian Germalus Stål, with new genera and further new species of Australian Geocorinae (Hemiptera: Heteroptera: Geocoridae). - Zootaxa 3746(2): 257-300. https://doi.org/10.11646/ zootaxa.3746.2.3

Mittermeier, R. A., Myers, N., Thomsen, J. B., Da Fonseca, G. A. \& Olivieri, S. (1998): Biodiversity hotspots and major tropical wilderness areas: approaches to setting conservation priorities. - Conservation Biology 12(3): 516-520 https://doi.org/10.1046/j.15231739.1998.012003516.x

Montandon, A. L. (1907): Nouveaux genres et espèces du groupe des Geocorinae. - Annales historico-naturales Musei nationalis hungarici 5: 89-97.

Montandon, A. L. (1913): Nouvelles études sur les Geocorinae (Hemiptera). - Bulletin Section Scientifique de l'Académiei Roumaine 2(1): 48-60.

Montrouzier, P. A. (1858): Description de quelques Hemiptères de Nouvelle Calédonie. Annales de la Société Linnéenne de Lyon 5: 243-260.

Montrouzier, P. A. (1861): Essai sur la faune entomologique de la Nouvelle-Calédonie (Balade) et des iles des Pins, Art, Lifu etc. Hémiptéres (1). - Annales Societé entomologique de France 4: 1-67.

Montrouzier, P. A. (1865): [Descriptions]. In Perraud, B. P. \& Montrouzier, P. A: Essai sur la faune entomologique de Kanala (Nouvelle Caledonie) et descriptions de quelques especes nouvelles ou peu connues. - Annales de la Societe Linneenne de Lyon (2)11: 46-257. 
Murienne, J., Guilbert, E. \& Grandcolas, P. (2009): Species' diversity in the New Caledonian endemic genera Cephalidiosus and Nobarnus (Insecta: Heteroptera: Tingidae), an approach using phylogeny and species' distribution modelling. - Biological Journal of the Linnean Society 97(1): 177-184. https://doi.org/10.1111/j.1095-8312.2008.01184.x

Myers, N., Mittermeier, R. A., Mittermeier, C. G., Da Fonseca, G. A. \& Kent, J. (2000): Biodiversity hotspots for conservation priorities. - Nature 403(6772): 853 https://doi. org/10.1038/35002501

Pascal, M., De Forges, B. R., Le Guyader, H., \& Simberloff, D. (2008): Mining and other threats to the New Caledonia biodiversity hotspot. - Conservation Biology 22(2): 498499. https://doi.org/10.1111/j.1523-1739.2008.00889.x

Schouteden, H. (1933): Hemiptera-Heteroptera. Résultats Scientifiques du Voyage aux Indes Orientales Néerlandaises de LL. AA. RR. le Prince et la Princesse Léopold de Belgique. Hemiptera-Heteroptera. - Mémoires du Musée Royal d'Histoire Naturelle de Belgique Hors Série 4(8): 1-70.

Tsai, J. F., Yang, M. M., RédeI, D. \& YeH, G. F. (2011): Jewel bugs of Taiwan (Heteroptera: Scutelleridae). - Chung Hsing University, 309 pp.

Received February 2, 2020, accepted June 13, 2020, published November 13, 2020 